How to Cite

Nindhom, A. A. (2019). Catfish livestock for society. International Journal of Life Sciences \& Earth Sciences, 2(1), 19-24.

https://doi.org/10.31295/ijle.v2n1.75

\title{
Catfish Livestock for Society
}

\author{
Aris Al Nindhom \\ STIKOM Bali, Denpasar, Indonesia \\ Email: nindhom@gmail.com
}

\begin{abstract}
Catfish farming is a profitable business that clicking because some may eat themselves and partly the result can be sold and an additional income for working on it. African catfish fish marketing today quite well and smoothly. Either in the form of seeds and meat or size consumption. In order to meet the demand for fish catfish in the market, farming catfish in pools - needs to be improved. By increasing its cultivation, the production will increase and supply in the market is also no shortage again. Dalam catfish farming, there two major activities that must be improved simultaneously, namely business hatchery (which provides seed) which includes aircraft maintenance, container and substrate preparation, selection of parent ready Pijah, spawning, hatching.

Keywords---catfish, consumption, farming, fish, market.
\end{abstract}

\section{Introduction}

Indonesia is a vast country and rich in biodiversity, such as catfish (C lariasbatrachus). Catfish farming has been done by the community, especially with the proliferation of Enterprises Warung Pecel Catfish in Jakarta, Bogor, Depok, Tangerang, and Bekasi (Jabodetabek). Catfish has long been one commodity that is very popular among the people.

Prior to the 1990s, according to the community, catfish is an animal that shapes like solar and living in a dirty place. But this time the prestige of catfish to rise. Catfish popularity not only in the country alone. According to the news Fish Market (2006) that in Melbourne, Australia Indonesia societies began to introduce commodity in the community.

\section{Objectives}

The purpose of writing this research report are:

1) To find better ways to cultivate catfish.

2) To know way to obtain quality seeds

3) To determine the types of catfish

4) Complete Indonesian task.

\section{Limitations}

As we studied about catfish are as follows:

1) The types of catfish.

2) Classification and deployment catfish.

3) The proliferation of catfish.

4) Habitat and behavior catfish.

5) Feature parent and how to spawning.

6) How stocking and harvest.

ISSN 2632-9425

Received Jan 20, 2019 / Accepted Jun 18, 2019 / Published Jul 05, 2019 


\section{Benefits}

The benefits of this research activity are to increase our knowledge about the cultivation of Catfish. And also fatherly provide readers informed about the procedures for the cultivation of catfish (Agrahari \& Gopal, 2009; Balamurugan et al., 2012).

\section{Theoretical Basis}

\section{Basic Theory}

Catfish is one of the leading commodity. Development efforts can be made from the seed to the size of consumption. Each business segment is highly profitable. In addition to local consumption, the market has started to export catfish and demand is quite large. The rate of increase in national consumption of catfish production increase of $18.3 \%$ per year. In 1999 amounted to 24991 tonnes of catfish production in 2003 amounted to 57740 tonnes of catfish production.

Revalitas catfish up to the end of 2009 is expected to reach production of 175,000 tons or an average increase of $21.64 \%$ per year. Catfish seed requirement level is also increasing rapidly. In 1999 it takes 156 million head in 2003, required 360 million head, whereas at the end of 2009 is estimated to be needed 1.9 billion birds or increased by $46 \%$ per year (Barnett, 2005; Chontananarth et al., 2014).

\section{Types of catfish Cultivated}

Catfish types, grown in Indonesia and found in the market today is the African catfish (Clariasgariepinus). In fig sec intensive aquaculture, catfish encouraged to grow maximum to reach the optimal size. African catfish is a commodity that can be maintained with high stocking density within a limited area (save land) in the marginal area and water-saving. For pool size of $15 \mathrm{~m}^{2}$ African catfish can be stocked as many as 5,250 fries. During the 2, 5 months catfish can be produced as much as $450 \mathrm{~kg}$ with a value of FCR (Fed Conversion Ratio) one.

Meanwhile, local catfish (ClaniusBatracus) are scarce and rarely found because growth is slower than the African catfish. In general, a figure similar to the local catfish African catfish, just his size is not as big as African catfish. In this paper will be a lot of discussion about African catfish, in particular also seeding stage and enlargement.

\section{Research Methodology}

In this study, we report the results of using the method to compile the literature we read of the literature. The definition of literature is the preparation method using a method based reading research literature on the object under study. From this literature, we can prepare a report on these results and know the ins and outs of farming catfish ranging from cultivation to post-harvest handling. In addition, we also know about the nature and habitat of live catfish (de Oliveira et al., 2015).

\section{Data Analysis}

\section{Environmental and Future of Marriage Catfish}

Although we've been able to know the catfish farming techniques, it is not optimal. Errors in processing can adversely impact the viability of our efforts to cultivate catfish.

a) Classification

In the classification, catfish, including families Clariide, the type of fish that have a flattened head shape and has an additional breathing apparatus. Systematics and classification are as follows:

1) Phylum: Chordata (nation vertebrate)

2) Class: Pisces (breathing with gills)

3) Sub Class: Tekstil (fish ray-loud)

4) Order: Ostariophysi (fish upper bones as tools and equipment balance is called bone Weber). 
5) Sub Order: Silurodea (fish's body shape length scales and slippery).

6) Genus: Clarias

7) Species: ClariasSp

b) Spreading catfish

Catfish are found in Africa and Southeast Asia. The mention of the name of catfish in various different countries, namely:

1) In Malaysia called: Keli

2) In Thailand called: Plamondon

3) In Japan called: center Tang

4) In Africa called: Mali

5) In Sri Lanka called: GuraMagura

6) In the UK called: Ct Fish

A Morphological Anatomy $\varnothing$

Generally, catfish has a slim body, not flaky, grouse and a mustache.

\section{Breeding}

Catfish in the wild spawn at the start of the rainy season. Stimulation in nature is closely linked to the increase in the volume of water that usually occurs during the rainy season, and the availability of micro-organisms (natural food), catfish aroused spawn after heavy rains and smells soil enough to sting (smell Ampo) as a result of dry soil exposed to rain too, Due to an increase in water depth, catfish like Elijah in the shade and protected. Catfish breed ovipar (external).

At the local catfish hatcheries in the pool can be two ways, namely by pairing and mass, local catfish will usually be loyal to her partner that is by putting a male and female catfish in a pond. With catfish male or female is ready to spawn, catfish will take turns to guard their eggs. Farmed catfish can be bred throughout the year as long as it is managed properly. Stimuli that do not use using harman but by clearing the pool, sunning and fill it and cause odor AMPA. The smell that stimulates the parent fish to spawn. Spawning can be done the afternoon or evening after the day is filled eggs. Furthermore, kakaban transferred to new containers to be incubated until hatching sized seed time required to hatch about 24-40 hours. The larvae aged 1-9 days still obtain feed from the yolks are still attached. Then the silkworm larvae hereinafter (Hegg et al., 2015; Özogul et al., 2007).

Type catfish excel:

a) Catfish Dumbo

Type catfish widely cultivated and found on the market today. While local catfish is rarely found because its growth is slower than the African catfish. Differences in local African catfish and catfish the size of Dumbo is greater than the local catfish. Comparison of the growth rate of African catfish and catfish local aged 2 days. African catfish from 1.2 to 39, while the local catfish 0.2 - 29. Age Dumbo catfish week 10-159, while the local catfish 1-159.

b) CatfishSangkuriang

One seed varieties are the dumbo catfish. Catfish is a marriage between African catfish females with males F2 F6 produce male African catfish F2 - 6. Then back mated with the female African catfish F2 to produce catfish. The trial results and studies proved superior catfish sangkuriang kinds of African catfish. However, catfish are still scarce in the market.

c) Catfish python

Catfish python is the result of a marriage between a female parent catfish former Thailand with the male African catfish F6. The advantage of catfish python faster growth, the survival rate is high and relatively resistant to the disease.

\section{Habitat and Behavior}

Habitat or environmental catfish commonly found in freshwater in lowland areas such as the former slightly brackish ponds. This area many residents of the north coast of Java, West Java such as Kendal widely used for catfish enlargement Dumbo. In nature, many catfish live in the rivers that flow is flowing slowly, and many also live in the area reservoirs, ponds, swamps and pools of fresh water, such as pools and more. Because of catfish like still water, such as regional banks of the shallow and protected. Catfish have a habit of making a hole in the bank of the river or pond. 
Catfish rarely reveal their activities during the day, catfish prefer a dark and shady too deep. Because catfish animals that have a tendency natural activity and foraging at night. During the day the catfish choose to hide in dark places. Catfish can withstand relatively homely environment and very little oxygen content. However, growth will be more catfish healthy and maintained sufficient clean water sources, such as rivers, springs, irrigation canals, or well water.

\section{Eating Habits}

Catfish has a habit of eating at the bottom of the water or the pool. Catfish are carnivores (meat eaters). In its natural habitat, catfish mealworms, water snails, grubs, moths, insect larvae, water fleas, etc. Additional good feed for catfish is a lot of animal protein. If the feed contains a lot of vegetable protein slow growth. Catfish are animals that like to eat its own kind (cannibalism) if catfish lack of food. Therefore do not be late feeding the cannibalistic nature timbula also because of the size difference.

\section{Preparation of Parent}

The mother should be maintained separately in its own pool with a male parent. Swimming specifically aims to accelerate the process maturity of gonads. Deviations parent who has mated, and simplify the management, control and prevent the occurrence of spawning out of the will-keeping. The characteristics of female and male parent catfish ready Pijah.

Table 1

The characteristics of the male and female parent

\begin{tabular}{|c|c|}
\hline Females & Parent Males \\
\hline $\begin{array}{l}\text { - Stomach enlarged/swollen and feels soft when } \\
\text { touched. } \\
\text { - Its movements are slow and docile. } \\
\text { - The genitals are round, reddish and appear swollen. } \\
\text { - The body color turns into a reddish-brown. } \\
\text { - If the stomach is massaged sometimes dark yellow } \\
\text { liquid out. }\end{array}$ & $\begin{array}{l}\text { - Tool sex flushed. } \\
\text { - The genitals seem clear and pointed. } \\
\text { - The body lean and agile movements. } \\
\text { - There is a change in skin color becomes reddish } \\
\text { brown. }\end{array}$ \\
\hline
\end{tabular}

\section{Giving}

Giving was a stage in the spawning is done when the parent fish satisfied finishes are selected and before spawning 1-2 days. Giving male and female parent must be in containers moved. Giving function is to eliminate stress at the time of the arrest. Besides reducing the fat content in the gonad and female parent to convince the election results. Upon maturity given parent female catfish checked restoring, if the mother becomes a flat stomach, distended means for their feed is not for their eggs.

\section{How Hatchery and Spawning}

The hatchery is an attempt to produce seed fish (catfish) at a certain size. To support the seeding process takes pond catfish spawning, hatching tub and pond. Here are some alternative kinds of container/spawning ponds, hatcheries, and nursery that can be used by growers.

a) Spawning Pool

Spawning pond is a special pool for the parent to spawn. The pond is used for breeding of catfish namely cement tanks, plastic sheeting and fiberglass tubs.

1) Bak Cement

Size tubs for one pair parent spawning catfish will be spawning is $1 \mathrm{mx} 2 \mathrm{~m}$ with $0.8 \mathrm{~m}$ tall tub. Before use, spawning tubs should be cleaned and dried. Furthermore, tubs filled with clear water and clean as high as $40-50 \mathrm{~cm}$.

2) Bak Plastic Sheeting 
Lebihmudah sheeting procurement compared with the manufacture of cement tanks. How made by preparing number brick around the periphery of plastic. Tub size tarps for spawning are $1 \mathrm{~m}$ wide, $2 \mathrm{~m}$ long and $0.8 \mathrm{~m}$ high. The measure used for a pair of holding catfish will be spawning.

3) Fiberglass

Fiberglass size for spawning catfish, namely $1 \mathrm{mx} 2 \mathrm{~m}$, and $0.8 \mathrm{~m}$ high. The size of the tub can be used for spawning a pair parent catfish. Bak Fiberglass relatively practical because of its location can be moved, but the price is still too expensive.

b) Bak Hatching

Catfish eggs hatching container can be a tank, cement tanks, tubs of plastic sheeting and fiberglass equipped with a generator to supply dissolved oxygen. But the object of catfish farms in our study using the bathtub size cement hatching $1 \mathrm{mx} 2 \mathrm{~m}$ with $0.8 \mathrm{~m}$ tall tub.

\section{Stocking and Harvesting}

\section{Spreading Seeds}

Seed catfish can already be provided in basins or open after 3-week-old seed. When stocking of fish pond water level of about $20-30 \mathrm{~cm}$, because the seeds are still small. How stocking of catfish is by way of acclimatization which contains seeds catfish and placed slowly, after which the seed was to adapt, the seeds will be off by itself. Seed density ranges from 300-600 fish / $\mathrm{m}^{2}$.

Once the seeds are in the pond, catfish fed with pallets of seed powder with a protein content of at least 40\% (Charoen Pokphand Code 581). Once the seeds are rather large, pallet feeding nanoparticulate form with a protein content of $38 \%$ FF code is 999 . The larger the body and mouth openings. The larger the size of the feed, the frequency of feeding catfish are still small at 4-5 times a day, the morning, afternoon, evening and night.

\section{Seed Harvesting}

Old nursery seed to produce seed catfish ready on the latest $(<5-7 \mathrm{~cm} /$ tail $)$ approximately 5-6 weeks. Harvesting the seeds can be done that afternoon or early morning when the temperature is not too hot. Harvesting by reducing the water slowly until the water is at kemalir. Venting water slowly until the water will accumulate in a puddle near the door expenditure. Harvesting is done by gradually using seser smooth. Keep the seed catfish was not injured. At the time of harvesting the seed size range $5-7 \mathrm{~cm} /$ tail.

\section{How to Harvest Catfish Enlargement Results}

How to harvest catfish consumption depending on system size pool. If in the concrete basins commonly used models rocking pipe or Siphon system. The working mechanism of such a system of pipes U. This system enables easy replacement of water, the pipes of PVC with a diameter of 3-4 inches. Used to set the current water level of maintenance as well as sewer water harvesting date.

The stages:

1) Disconnect the pipe connecting the horizontal drain for draining.

2) Put a colander or wire gauze at the end of the PVC pipe inside the sewer in order catfish do not go with the flow.

3) Stop draining if the water level reaches $20-30 \mathrm{~cm}$.

4) Take catfish with nets / seser.

5) Enter the catfish into the crack bucket (bucket cavity).

6) Pick up and fill the bucket to the shelter.

7) Sort return catfish is based on the desired size (8-12 tails/kg), then weigh it and insert it into the transport container.

8) Maintain back less catfish small to reach market size.

9) Make less big catfish as the sire or sold to the fishing grounds. 


\section{Tips Agribusiness Catfish}

Market and enterprise business was unusually large catfish. This can be seen with the proliferation of kiosk pecel catfish. However, at such high desire for agribusiness catfish are often not accompanied by an appropriate strategy. Not infrequently sunk capital depleted and even add a little debt. The success of agribusiness fisheries require in-depth knowledge and comprehensive between technical and non-technical terms in catfish farming.

\section{Conclusions}

Once we know the catfish farming technology, now comes the last chapter on the analysis of catfish farming. Catfish have been cultivated by the people of Indonesia. This was driven by the increasing number of stalls opened pecel catfish. The more days pecel catfish enthusiasts is increasing, it is probably because pecel catfish taste very delicious. Whereas before the 1990s people thought that the catfish as a ridiculous beast. But at this moment the situation changed. The prestige of catfish to be increased, even by Warta Fish Market (2006) that in Melbourne Australia Indonesian people have started to introduce these commodities in the community.

\section{Suggestions}

We as authors are well aware that research is still very far from perfect. Thus the authors are expecting further research on Aquaculture Catfish. We very much hope that catfish farming can continue to be preserved.

\section{References}

Agrahari, S., \& Gopal, K. (2009). Retracted: Fluctuations of certain biochemical constituents and markers enzymes as a consequence of monocrotophos toxicity in the edible freshwater fish, channa punctatus. https://doi.org/10.1016/j.pestbp.2009.02.001

Balamurugan, S., Deivasigamani, B., Kumaran, S., Sakthivel, M., Rajsekar, T., \& Priyadharsini, P. (2012). Melanomacrophage centers aggregation in P. lineatus spleen as bio-indicator of environmental change. Asian Pacific Journal of Tropical Disease, 2, S635-S638. https://doi.org/10.1016/S2222-1808(12)60235-7

Barnett, J. B. (2005). Marine science journals and serials: 1993-2003 Update. Science \& Technology Libraries, 25(4), 87-102. https://doi.org/10.1300/J122v25n04_07

Chontananarth, T., Wongsawad, C., Chomdej, S., Krailas, D., \& Chai, J. Y. (2014). Molecular phylogeny of trematodes in family Heterophyidae based on mitochondrial cytochrome c oxidase subunit I (mCOI). Asian Pacific journal of tropical medicine, 7(6), 446-450. https://doi.org/10.1016/S1995-7645(14)60072-9

de Oliveira, I. S., Lourenço, L. D. F. H., Sousa, C. L., Joele, M. R. S. P., \& do Amaral Ribeiro, S. D. C. (2015). Composition of MSM from Brazilian catfish and technological properties of fish flour. Food Control, 50, 38-44. https://doi.org/10.1016/j.foodcont.2014.08.018

Hegg, J. C., Giarrizzo, T., \& Kennedy, B. P. (2015). Diverse early life-history strategies in migratory Amazonian catfish: implications for conservation and management. PLoS One, 10(7), e0129697. https://doi.org/10.1371/journal.pone.0129697

Özogul, Y., Özogul, F., \& Alagoz, S. (2007). Fatty acid profiles and fat contents of commercially important seawater and freshwater fish species of Turkey: A comparative study. Food chemistry, 103(1), 217-223. https://doi.org/10.1016/j.foodchem.2006.08.009 